\title{
Mackie vs Plantinga on the warrant of theistic belief without arguments
}

\section{DOMINGOS FARIA}

University of Lisbon, Center of Philosophy of the University of Lisbon, LanCog df@domingosfaria.net

\begin{abstract}
My aim in this paper is to critically assess two opposing theses about the epistemology of religious belief. The first one, developed by John Mackie, claims that belief in God can be justified or warranted only if there is a good argument for the existence of God. The second thesis, elaborated by Alvin Plantinga, holds that even if there is no such argument, belief in God can be justified or warranted. I contend that the first thesis is plausibly false, because belief in God is not just like a scientific hypothesis, and the second thesis is likely true if epistemic externalism is the correct view. However, even if the second thesis is true, I argue that to work on good arguments for God's existence is unavoidable in order to cope with a new version of the Great Pumpkin objection, as well as to achieve other relevant purposes such as to convince rational observers outside the theistic community that belief in God is likely justified or warranted.
\end{abstract}

Keywords: epistemology of religious belief; warrant; theistic belief; natural theology; mackie; plantinga.

\section{Introduction}

It seems that most people accept some form of theism (cf. The World Factbook 2013-14, CIA). "Theism" or "theistic belief" is the belief that there is a God, as conceived of in the central tradition of the main monotheistic religions (Judaism, Christianity, and Islam), in which God is seen as a per- 
sonal, omnipotent, omniscient, omnibenevolent being, etc. But why do these people accept that belief? How can they be justified or warranted in believing that there is a theistic God? By "justification" or "warrant" I mean the property that distinguishes knowledge from mere true belief. ${ }^{1}$ In other words, it is that quality or quantity which, in due measure and together with truth and belief, is sufficient for knowledge. So, we need to ask: Is theistic belief justified or warranted for those people who believe in God?

At first glance we may be inclined to assert that they are justified or warranted in those beliefs only if they have a successful theistic argument, i.e., a good (noncircular) argument that proves that God exists. For that purpose, there have been some attempts, like the ontological argument, the cosmological argument, the teleological argument, etc. However, those people who believe in God do not usually resort to proofs or arguments for justifying their theistic belief. Certainly most of them have not even heard of these theistic arguments. Instead it seems that they believe in God in a basic way and in circumstances of religious experience. Here, by speaking of "religious experience" I mean to focus on common or everyday experiences of faith rather than extraordinary experiences (such as the witnessing of miracles or mystical experiences). More precisely, I mean experiences of praying, reading the Bible, attending Mass, feeling guilt or gratitude, facing danger, or simply contemplating the beauty of nature, and so on, in which one may be said to sense God's presence or something of the sort.

Now the problem I want to pose is the following: Can theistic belief be justified or warranted (by way of religious experience) without a successful theistic argument? This amounts to asking whether theistic belief can be properly basic. By "basic belief" I mean the following: a belief $\mathrm{p}$ at time $\mathrm{t}$ is basic for a person $\mathrm{S}$ iff $\mathrm{p}$ at $\mathrm{t}$ is such that it is accepted by $\mathrm{S}$ but not on the basis of any argument; in other words, $p$ at $t$ is such that it is not arrived at by way of any inferences from S's other beliefs. And by “properly basic belief" I mean the following: a belief $\mathrm{p}$ at time $\mathrm{t}$ is properly basic for a person

1 Plantinga (1993a, 4-5) prefers to use the term "warrant" instead of "justification" as a name for such a property, because the term "justification" seems to suggest a deontological affair while "warrant" is more neutral. However, here I am using "warrant" and "justification" as synonymous. 
$\mathrm{S}$ iff (i) $\mathrm{p}$ is a basic belief at $\mathrm{t}$ for $\mathrm{S}$ and (ii) $\mathrm{p}$ has justification or warrant at $\mathrm{t}$ for S. ${ }^{2}$ So, our problem is to survey whether theistic belief can be properly basic in circumstances of religious experiences. There are at least two theses in dispute to answer this problem, namely:

(T) It is necessary that if theistic belief has warrant (for example, by way of religious experience), then there is a successful theistic argument.

$(\sim \mathrm{T})$ It is possible that theistic belief has warrant (for example, by way of religious experience) even if there isn't any successful theistic argument.

The first thesis $(\mathrm{T})$ expresses that theistic belief can get no warrant unless there is a good theistic argument, whereas the second thesis $(\sim \mathrm{T})$ asserts that even if there are no such good theistic arguments, theistic belief can be warranted. More rigorously and in logical notation, where "W" stands for "theistic belief is warranted" and "A" stands for "there is a successful theistic argument":

$(\mathrm{T}) \square(\mathrm{W} \rightarrow \mathrm{A})$

$(\sim T) \diamond(\mathrm{W} \wedge \neg \mathrm{A})$

My aim in this paper is to show that (i) if epistemic externalism is true, thesis $(\sim \mathrm{T})$ is plausible; but, (ii) even if $(\sim \mathrm{T})$ is true, it is necessary to have good theistic arguments for some purposes, namely to cope with a new version of the Great Pumpkin objection and to convince rational observers outside the theistic community that belief in God is likely justified or warranted. In order to accomplish this goal, I draw on the following plan: in §1 I present and criticize John Mackie’s argument for (T); in §2 I review Alvin Plantinga's argument for $(\sim \mathrm{T}) ;^{3}$ and finally in §3 I argue for the role that theistic arguments play even if thesis $(\sim \mathrm{T})$ is true.

2 Here I am following Plantinga's definition of basicity (cf. 1993a, 70; 2000, 178; 2015, 36).

3 In this paper I present the argumentation of Mackie and Plantinga because they illustrate very well the theses in dispute, $(\mathrm{T})$ and $(\sim \mathrm{T})$. But we could present similar arguments for such theses. For example, Martin (1990), Sobel (2003), Oppy (2009), and Draper (2013) seem to argue for thesis (T), whereas Wolterstorff (1988), Alston (1991), S. Evans (2011), and Bergmann (2012) seem to argue for thesis ( T). 


\section{Mackie's argument for (T)}

In order to present Mackie's argument it is worth reading some quotes. In Mackie's book The Miracle of Theism (1983) we find the following:

(Q1) "If it is agreed that the central assertions of theism are literally meaningful, it must also be admitted that they are not directly verified or directly verifiable. It follows that any rational consideration of whether they are true or not will involve arguments. [...] It [whether God exists] must be examined either by deductive or inductive reasoning or, if that yields no decision, by arguments to the best explanation; for in such a context nothing else can have any coherent bearing on the issue" $(1983,4,6)$.

(Q2) "If the religious experiences do not yield any argument for a further supernatural reality, and if [...] there is no other good argument for such a conclusion, then these experiences include in their content beliefs that are probably false and in any case unjustified. This, it seems, must be scored as a disvalue against them" $(1983,186)$.

In these quotes, Mackie seems to make the following assumptions:

(A1) Theistic belief has justification or warrant only if there is a successful argument (deductive, inductive, or abductive) for the existence of God.

(A2) Theistic belief has justification or warrant by way of religious experience only if there is a successful theistic argument from religious experience. ${ }^{4}$

But why does he think that assumptions (A1) and (A2) are true? Mackie makes these assumptions because he thinks that theistic belief is just like a scientific hypothesis (i.e. a theory designed to explain some body of evidence). Furthermore, he assumes that rational acceptability of theistic belief (like any scientific hypothesis) depends upon its success as a hy-

4 A successful theistic argument from religious experience is a good (noncircular) argument from premises reporting the occurrence of such religious experiences to the conclusion that God exists. And such an argument would have to include as a premise the proposition that the existence of God is the best explanation of religious experiences. 
pothesis. ${ }^{5}$ So, in this view, a hypothesis is acceptable to the extent that it succeeds in explaining the evidence. And is the theistic belief a good hypothesis? Speaking about religious experience, Mackie holds that:

(Q3) "Religious experience is also essentially incapable of supporting any argument for the traditional central doctrines of theism. Nothing in an experience as such could reveal a creator of the world, or omnipotence, or omniscience, or perfect goodness, or eternity, or even that there is just one god" $(1983,182)$. (Q4) "Here, as elsewhere, the supernaturalist hypothesis fails because there is an adequate and much more economical naturalistic alternative" $(1983,198)$. For that reason, Mackie says that "In the end, therefore, we can agree with what Laplace said about God: we have no need of that hypothesis” $(1983,253)$.

Bearing all these passages in mind, I think that a possible formulation of Mackie's argument would be as follows:

(1) Theistic belief is just like a scientific hypothesis, designed to explain religious experience (among other things).

(2) If theistic belief is just like a scientific hypothesis, then (like any other scientific hypothesis) theistic belief has warrant by way of religious experience only if some theistic argument (from religious experience or similar) is successful.

(3) $\therefore$ So, theistic belief has warrant by way of religious experience only if some theistic argument (from religious experience or other) is successful. [From 1 and 2]

(4) But there isn't any successful theistic argument (from religious experience or similar).

(5) $\therefore$ Therefore, theistic belief has no warrant by way of religious experience. [From 3 and 4]

Is this a good argument? There are ways to object to it. One such way is to challenge premise (4). For example, Swinburne (2004, ch. 13) tries to

This idea is also shared by Wilson $(1978,201)$ and Dawkins $(1995,46-47)$. 
provide a good theistic argument from religious experience in order to show the rationality of theistic belief. However, he seems to accept both of Mackie's assumptions, (A1) and (A2), and, for that reason, he also seems to assent to thesis $(\mathrm{T})$. Another way to reply to Mackie's argument, while rejecting his assumptions, is to deny conclusion (3) and premise (1). This way of replying was essayed by Plantinga. Since this last objection criticizes the assumptions which are related with thesis $(\mathrm{T})$, it is worth analyzing it in detail. So, why does Plantinga think that steps (1) and (3) are false?

We have seen that conclusion (3) of Mackie's argument is true only if we think of theistic belief just as a scientific hypothesis: namely, (i) a theory designed to explain some body of evidence and (ii) acceptable to the degree that it succeeds in explaining the evidence. But why think that theistic belief or theism is just like a scientific hypothesis? Plantinga argues that we don't think the same about belief in other minds, the past, the existence of the external world, etc. - such beliefs are not thought of as a scientific hypothesis (at least they need not be considered just like scientific hypotheses). So, why couldn't the same hold for theistic belief? Why think that theistic belief is substantially different from our common beliefs? Mackie did not show it.

By reductio ad absurdum, Plantinga (2000, 92, 330; 2015, 83) argues that if Mackie is correct, we can also think that our beliefs about the past are just like scientific hypotheses. And if such beliefs are just like scientific hypotheses, then they are designed only to explain present phenomena such as our memories. If this is so, and if there were a more «economical» explanation of these phenomena that did not postulate past facts, then our usual beliefs in the past would have no warrant or justification. However, this seems silly; because the availability of such an "explanation" wouldn't in any way tell against our ordinary belief that there has really been a past. Furthermore, usually we don't accept beliefs about the past as hypotheses to explain present experience or phenomena. Therefore, it seems that Mackie is not correct.

In other words: if Mackie's argument is sound, we can also think that our common beliefs are just like scientific hypotheses. And if we think 
that common beliefs should be just like scientific hypotheses, then many reasonable beliefs, such as those about other minds, the past, material object, perceptual beliefs, external world, etc., turn out to be unjustified or unwarranted (because commonly we accept those beliefs without arguments and not for explanatory purposes). But such a conclusion is absurd. Thus, we do not need to think of those beliefs (including theistic belief) as similar to scientific hypotheses.

Plantinga, thus, argues that conclusion (3) of Mackie's argument is unestablished, because premise (1) is false. This is because theistic belief is not, or at least need not be considered to be, just like a scientific hypothesis, but is more similar to our perceptual beliefs or the belief in other minds, the past, material objects, external world, etc. And these beliefs can be justified or warranted even if there isn't a good argument for them. Commonly we accept these beliefs in a basic way and without arguments. So, Mackie's argument is not a good reason for thinking that theistic belief is warranted or justified only if there is a successful theistic argument.

I think Plantinga is right to deny premise (1). We can add other arguments in order to show that theist belief need not be considered as a scientific hypothesis. For many believers in God, the primary aim of theistic belief or faith is not to explain or predict natural events in the world; so, these people do not consider typically their faith just like a scientific hypothesis postulated to explain observable events. Instead, for such people, theistic belief or faith is concerned with trust and love to a person: God ${ }^{6}$. It seems more an expression of an experience of encounter rather than an inferential hypothesis. If this is correct, theistic belief is more like belief in other people than belief in the existence of electrons or genes.

In this regard, we can make an analogy: I believe that my wife Vera loves me. I do not consider this belief a hypothesis; but if such belief were for me just like a scientific hypothesis, it would be too weird (something would not be right with our relationship). Plausibly something similar happens to believers in God. Nonetheless, even if I do not think my belief

6 In this sense, faith not only has a propositional content, but also has an affective component. 
that my wife loves me as a hypothesis, occasionally someone else could consider such belief as a hypothesis. Suppose that my friend Joseph heard me say that my wife loves me. He doubts whether that belief is true and, for that reason, treats my belief as a hypothesis, trying to gather proofs for and against it. There is nothing wrong with such behavior. Likewise, some unbeliever could think of theistic belief as a hypothesis, trying to collect arguments for and against the existence of God. Once again, neither is there anything wrong with such behavior here; but this is not to defend Mackie's thesis that theistic belief can only be like a scientific hypothesis for any given person. Even if someone treats my belief that my wife loves me as a hypothesis, I do not need to think such belief as a hypothesis. Likewise, generally believers in God do not need to think theistic belief as a hypothesis, even though someone else may do it.

\section{Plantinga's argument for $(\sim \mathrm{T})$}

In the previous section we saw that thesis $(\mathrm{T})$ does not seem very well grounded, since we do not need to think theistic belief as a scientific hypothesis. Now we need to ascertain whether thesis $(\sim \mathrm{T})$ fares any better. According to thesis $(\sim \mathrm{T})$, it is entirely possible that theistic belief has warrant even if there is no good theistic argument (from religious experience or similar), even if such belief is not based on proofs or arguments. ${ }^{7}$ In other words, theistic belief can be properly basic. But how is that possible? How can belief in God be properly basic? Following Plantinga's reasoning, we must first enquire what the warrant is. So, what is that which fills the gap between mere true belief and knowledge? According to Plantinga, there are three main views as to the nature of warrant:

This thesis should not be confused with fideism (such as advocated by Pascal, William James, Kierkegaard, or Wittgenstein) in which theistic belief can be at most prudentially justified, but not epistemically justified, nor requiring any evidence. On the contrary, thesis $(\sim T)$ holds that theistic belief can be epistemically justified, requires evidence (namely, non-propositional evidence, such as experiences [cf. Plantinga 1993b, 185-193; 2008, 164-165]), and can have the status of knowledge. 
(W1) Deontologism ${ }_{\mathrm{df}}$ a belief $\mathrm{p}$ has warrant for $\mathrm{S}$ iff believing $\mathrm{p}$ is an especially good way for $\mathrm{S}$ to fulfill his epistemic duty.

(W2) Coherentism ${ }_{\text {df }}$ a belief $p$ has warrant for S iff $p$ is coherent with noetic structure of $\mathrm{S}$.

(W3) Reliabilism ${ }_{\text {df }}$ a belief $\mathrm{p}$ has warrant for $\mathrm{S}$ iff $\mathrm{p}$ is produced in S by a process that reliably leads to true beliefs.

The views (W1) and (W2) are internalist, whereas (W3) is externalist. On the one hand, "internalism" is the view that each of the conditions which are individually necessary and jointly sufficient for warrant is an internal condition, of which the subject is or may be aware. On the other hand, "externalism" is the view that at least one of the conditions which are individually necessary and jointly sufficient for warrant is an external condition. ${ }^{8}$ Plantinga (1993a) argues that none of these three views are really viable. This is because there are some counterexamples to the necessary and sufficient conditions proposed by theories (W1) and (W2), and against the sufficient condition proposed by (W3). In short, "these views are subject to counterexamples in which a true belief fulfills all of the specified conditions for warrant and, yet, manages to fulfill them «merely by accident»" (2012, 127). In order to overcome these counterexamples, Plantinga holds that an adequate analysis of warrant must involve the notion of "proper function.” As such, Plantinga (1993b; 2012) thinks that the best theory of warrant is "proper functionalism" which can be defined as follows:

Proper functionalism $(\mathrm{PF})={ }_{\mathrm{df}}$ a belief $\mathrm{p}$ has warrant for a person $\mathrm{S}$ iff ${ }^{9}$

(1) $\mathrm{p}$ is produced in S by cognitive faculties functioning properly (subject to no dysfunction). [The proper function condition] $]^{10}$

8 Here I am following the definitions of Plantinga (1993a, 5-6, 183) and Bergmann (402).

9 In addition to these conditions, Plantinga (1993b, 7-9) holds that warrant comes in degrees. Thus, he claims that if both $\mathrm{p}$ and $\mathrm{p}^{*}$ have warrant for $\mathrm{S}$, $\mathrm{p}$ has more warrant than $\mathrm{p}^{*}$ for $\mathrm{S}$ iff S believes $\mathrm{p}$ more firmly than $\mathrm{p}^{*}$.

10 Plantinga (1993b, 9-10, 26-30) holds that a cognitive equipment functioning "properly" is not the same thing as it functioning "normally" (in a statistical sense), or functioning "perfectly" or even "ideally". Instead, a cognitive equipment is function- 
(2) $\mathrm{p}$ is formed in an appropriate epistemic environment (one sufficiently similar to that for which S's cognitive faculties were designed). [The environmental condition]

(3) S's cognitive faculties, which produce $p$, are operating according to a design plan reliably aimed at truth (rather than some other cognitive goal). [The reliability condition]

(4) S has no defeaters for $\mathrm{p}$. [The no-defeater condition]

Now, if proper functionalism (or some other similar externalist theory) about warrant is correct, can theistic belief have warrant? Can theistic belief be properly basic? In order to answer affirmatively, Plantinga proposes a model in which theistic belief is basic and warranted. This model is labeled "Aquinas/Calvin model" or "A/C model", because it is based on claims made by Thomas Aquinas and John Calvin. According to Plantinga, "to give a model of a proposition or state of affairs $\mathrm{S}$ is to show how it could be that S is true or actual" $(2000,168)$. Furthermore, the model itself is another proposition or state of affairs $S^{*}$, such that (1) $S^{*}$ is logically and epistemically possible and (2) if $S^{*}$ is true, then $S$ is true. From (1) and (2), it follows that $\mathrm{S}$ is logically and epistemically possible. And a model $\mathrm{S}^{*}$ is epistemically possible just in case $\mathrm{S}^{*}$ is consistent with what we know, where "what we know" is what all (or most) of the participants in the discussion agree on (cf. Plantinga 2000, 169; 2015, 31).

So, in giving the $\mathrm{A} / \mathrm{C}$ model, Plantinga wants to show that: (1) the $\mathrm{A} / \mathrm{C}$ model is possible [in a logical and epistemic sense] and (2) if the $\mathrm{A} / \mathrm{C}$ model is true, then it is true that theistic belief has warrant in a basic way. From that, it follows that it is possible that theistic belief has warrant in a basic way (i.e., without inferences or arguments). In other words, it follows that

ing properly (i) when it works in accord with its design plan (in other words, when it works just the way in which it was designed to work) and (ii) when it works in such a way as to fulfill its purpose or function (i.e. when it does what it was designed to do). By "design plan" Plantinga means a set of specifications according to which a thing (artifact, organism, or faculty) is supposed to work. And this design plan can be the result of conscious design (like God) or simply of unconscious design (like natural evolution). 
thesis $(\sim T)$ is true. Since, according to the possible state of affairs described in the $\mathrm{A} / \mathrm{C}$ model, theistic belief has warrant in a basic way, if that state of affairs is actual, then theistic belief has indeed warrant in a basic way. Moreover, if God exists, then very likely the A/C model (or something similar) is also true. Therefore, if God exists, then very likely the theistic belief has warrant in a basic way.

However, Plantinga doesn't want to prove that God exists or to show that the $\mathrm{A} / \mathrm{C}$ model is true or actual ${ }^{11}$. Instead, Plantinga merely wants to argue that (1) the $\mathrm{A} / \mathrm{C}$ model is epistemically possible and, for that reason, theistic belief can be warranted in a basic way [i.e., he wants to show that thesis $(\sim \mathrm{T})$ is true]; and (2) if God exists, likely theistic belief is warranted in a basic way. More rigorously, I think that we can formulate Plantinga's argument as follows (where "M" is "the A/C model is true or actual", "G" is "the theistic God exists", "A" is "there are successful theistic arguments", and "W" is "the theistic belief is warranted"):

First part of Plantinga's argument: ${ }^{12}$

$(1) \diamond \mathrm{M}$

$(2) \square(M \rightarrow \neg(\mathrm{W} \rightarrow \mathrm{A}))$

(3) $\therefore \diamond(\mathrm{W} \wedge \neg \mathrm{A})[$ from 1 and 2$]$

Second part of Plantinga's argument: ${ }^{13}$

(4) $\square(\mathrm{G} \rightarrow \mathrm{M})$

$(5) \therefore \square(G \rightarrow W)[$ from 2 and 4$]$

11 Plantinga (2000, 170, 201, 499) seems really skeptical of natural theology; for example, he claims that no argument with premises accepted by everyone or nearly everyone is strong enough to support theistic or Christian belief. But I suspect that this criterion of success for an argument is quite unreasonable; for instance, if we use this criterion, then the argumentation for $(\sim \mathrm{T})$ is unsuccessful.

12 For a similar formulation of the first part of the argument see MacIntosh (2000). The argument is valid in $\mathrm{K}$, the weakest system of modal logic; and if it is valid in $\mathrm{K}$, then it is also valid in all the other ones.

13 In more rigorous terms, Plantinga seems to present that argument in a probabilistic way and not in a deductive way. So, perhaps a more precise way to formulate the second part of Plantinga's argument is as follow: (4) $\mathrm{P}(\mathrm{M} \mid \mathrm{G})$ is high. (5) $\therefore \mathrm{P}(\mathrm{W} \mid \mathrm{G})$ is high. 
In this argument, on the one hand, conclusion (3) is the negation of (T) and the affirmation of $(\sim \mathrm{T})$. In other words, it is a reply to Mackie's thesis. On the other hand, conclusion (5) is a reply to the following de jure objection $^{14}$ : theistic belief, whether true or false, has no warrant (in a basic way); in other words, even if theistic belief is true, very likely it isn't warranted. However, if (5) is true, then no de jure objection is compatible with the truth of the theistic belief; i.e., there aren't any viable de jure criticisms that are compatible with the truth of the theistic belief.

This is a general formulation of Plantinga's argument. Now, we need to grasp some details of this argument. For example, in what consists the $\mathrm{A} / \mathrm{C}$ model ${ }^{15}$ How is the $\mathrm{A} / \mathrm{C}$ model described? Plantinga asserts that the $\mathrm{A} / \mathrm{C}$ model is based on the assumption that we are God's creation, created in God's image, and on the claim made by Aquinas and Calvin that "there is a kind of natural knowledge of God" (2000, 170). For instance, according to Aquinas, "to know in a general and confused way that God exists is implanted in us by nature" (Summa Theologiae I, q. 2, a. 1, ad. 1), and according to Calvin, "there is within the human mind, and indeed by natural instinct, an awareness of divinity. [...] God himself has implanted in all men a certain understanding of his divine majesty" (Institutes of the Christian Religion I, iii, 1).

So, on the basis of such assumptions, ${ }^{16}$ there is a natural human tendency, a sort of instinct, to form beliefs about God under a variety of conditions and circumstances. In other words, there is a faculty or a cognitive mechanism, what Calvin describes as sensus divinitatis, a sense of divinity (hereafter SD), which in a wide variety of circumstances produces beliefs about God in human beings.

According to Plantinga, "the sensus divinitatis is a disposition or set of dispositions to form theistic beliefs in various circumstances, in response

${ }^{14}$ A de jure objection to theistic belief is the claim that such belief is unjustified or unwarranted; a common de jure objection holds that $\diamond(\mathrm{G} \wedge \neg \mathrm{W})$.

15 Plantinga also develops an "extended A/C model" in which Christian beliefs can have warrant. But, for our purposes and since we are considering theistic belief, we just need to focus on "the A/C model".

16 These ideas were already present in Paul's letter to the Romans (cf. Rom 1, 18-20). 
to the sorts of conditions or stimuli that trigger the working of this sense of divinity" (2000, 173). Moreover, it "is part of our original cognitive equipment, part of the fundamental epistemic establishment with which we have been created by God" (2000, 180). We can describe (cf. Miller 2005, 148) more rigorously the $\mathrm{SD}$ as follows:

(DSD) a person S forms a theistic belief as a result of the working of S's SD at time $t$ if (and only if):

(i) S's cognitive faculties at t include a SD (or similar);

(ii) $\mathrm{S}$ at $\mathrm{t}$ is in specific circumstances $\mathrm{C}$ which trigger $\mathrm{SD}$;

(iii) S's SD at $\mathrm{t}$ is functioning properly. ${ }^{17}$

But what are these circumstances $\mathrm{C}$ ? It is hard to give a rigorous characterization, but they might include common religious experiences, like praying, reading the Bible, attending Mass, feeling guilt or gratitude, experiencing danger, or simply contemplating the beauty of nature, and so on, in which one may sense God's presence or something akin to that. Such circumstances C can trigger SD and, if SD is working properly, theistic belief is formed. Using an analogy, we can hold that SD is like an input-output device: it takes the circumstances $C$ as input and issues as output theistic belief, if it is functioning properly.

However, on the A/C model, it is not the case that every person has theistic beliefs as a result of the operation of the SD. As with the other cognitive faculties, the SD of some people may be operating in an inappropriate environment and, for that reason, condition (ii) of (DSD) is not satisfied. Or the SD of certain persons may be operating with some dysfunction and, so, condition (iii) of (DSD) is not satisfied. For example, according to the $\mathrm{A} / \mathrm{C}$ model and if Christian history is true, original sin can damage

17 I am inclined to add a further condition which I think is crucial, although Plantinga makes no reference to it. This further condition is the free-will condition to accept or to reject the belief in God, and which can also explain the variability of belief in God or the unbelief (cf. Beilby 2007, 156-158). So, it might be relevant to add that: (iv) S freely accepts or is willing to accept what is produced by SD at $t$. 
the sensus divinitatis and compromises its operation (Plantinga 2000,184; 2015: 37). Other explanations for unbelief are given, for example, by Moser (2008), Greco (2008), Stump (2010), and Bergmann (2012).

Nevertheless, if all conditions of (DSD) are met, theistic belief is likely basic for the believer. In the same way that, in typical cases, human beings find themselves with perceptual and memory beliefs, in the absence of any inferences or arguments for such beliefs, so also theistic belief is typically formed in a direct or basic way in human beings who are in circumstances $\mathrm{C}$, like circumstances of religious experience. In this regard Plantinga claims that:

(Q5) "According to the A/C model, this natural knowledge of God is not arrived at by inference or argument (for example, the famous theistic proofs of natural theology) but in a much more immediate way. [...] These beliefs [about God] just arise within us. They are occasioned by the circumstances; they are not conclusions from them. [...] In this regard, the sensus divinitatis resembles perception, memory, and a priori belief" (2000, 175).

Thus, theistic belief is not acquired by way of inferences or arguments, but in a basic or immediate way. In other words, theistic belief produced by SD is not the conclusion of an argument, nor are the various circumstances $\mathrm{C}$ (that trigger the operation of the SD) premises for an argument. On the contrary, this is a belief that spontaneously arises in those circumstances $\mathrm{C}$, in a similar way to perceptive or memory beliefs. ${ }^{18}$ Therefore, according to a foundationalist epistemology, we can say that theistic belief is a basic belief, because this belief is not accepted on the basis of any arguments

18 Here Plantinga seems to hold a "parity thesis" in which beliefs which result from the operations of S's SD can play roughly the same foundational role in S as do those which result from S's cognitive faculties responsible for perception, memory, and a priori belief (cf. Miller 2005, 149). However, Plantinga does not hold that theistic belief is identical, in a phenomenological sense, to perceptual or memory beliefs. Instead, he only claims that what these beliefs share in common is the following: (i) they can be formed by cognitive faculties functioning properly in an appropriate environment; (ii) they can be both warranted in a basic way. But, other proponents of thesis $(\sim$ T), like Alston (1991), seem to go further holding that the warrant of theistic belief is indeed perceptual warrant. 
or inferences, it is not accepted on the evidencial basis of other beliefs or propositions.

Furthermore, on the A/C model and if all conditions of (DSD) are met, the theistic belief is not only basic but also properly basic, because it meets the conditions for warrant (Plantinga 2000, 179; 2015, 36-37), namely: the SD has been designed by God so that if it is functioning properly and under an appropriate epistemic environment (as the circumstances C), it produces true basic beliefs about God. In other words, a theistic belief $\mathrm{p}$ has warrant for a person $\mathrm{S}$, because $\mathrm{p}$ is produced in $\mathrm{S}$ by SD that it is properly functioning, in circumstances $\mathrm{C}$, according to a design plan, conceived by God, reliably aimed at truth. So, when the SD works in a proper way and under proper circumstances commonly it produces true theistic beliefs. Therefore, theistic belief produced by the SD can be properly basic with respect to warrant.

Now, given that the $\mathrm{A} / \mathrm{C}$ model seems to be consistent, it shows how theistic belief can be warranted without any good theistic argument; it indicates the possibility of theistic belief being warranted in a basic way. Thus, what we have seen so far was that once the $\mathrm{A} / \mathrm{C}$ model is possible, it follows that it is possible that theistic belief is warranted in a basic way, i.e., thesis $(\sim \mathrm{T})$ is true. But, is the $\mathrm{A} / \mathrm{C}$ model true or actual? Is theistic belief indeed warranted in a basic way? The answer is affirmative if theistic belief is true and, so, if God exists. Hence, if God exists, then the A/C model (or a similar one) is likely true and, for that reason, there is a cognitive faculty, like the SD, that produces theistic beliefs which are warranted in a basic way. Quoting Plantinga,

(Q6) If theistic belief is true, "then there is, indeed, such a person as God, a person who has created us in his image [...], who loves us, who desires that we know and love him [...]. But if these things are so, then he would of course intend that we be able to be aware of his presence and to know something about him. [...] Given that God would certainly want us to be able to know him, the chances are excellent that he would create us with faculties enabling us to do just that" (2000, 188-189). 
So, if theistic belief is true, then likely the A/C model (or similar) is true and, thus, likely theistic belief is warranted. However, what if theistic belief is false or if God doesn't exist? If God doesn't exist, likely theistic belief isn't warranted; because there isn't a SD and so on. Therefore, theistic basic belief has externalistic warrant (likely) if, and only if, there is God. In a general way I am inclined to consider that this line of argument for $(\sim \mathrm{T})$ likely is correct, if epistemic externalism (like proper functionalism theory) is true. But even if this argumentation is correct, I think (contrary to Plantinga) that theistic arguments are necessary for some purposes. Thus, working on natural theology or on natural atheology is unavoidable. ${ }^{19}$

\section{The role of theistic arguments even if thesis $(\sim T)$ is true}

Plantinga's project is to explain how theistic beliefs can be warranted and properly basic, as opposed to showing that they are so. In other words, Plantinga's project is to hold that (1) it is possible that theistic belief is warranted even if there isn’t any good theistic argument, i.e., thesis $(\sim \mathrm{T})$; and (2) if there is a God, likely theistic belief has warrant.

I think that this project, if successful, is sufficient to deny Mackie's thesis $(\mathrm{T})$, but at the same time it seems to me an insufficient project. There are relevant questions, like: Is the $\mathrm{A} / \mathrm{C}$ model true or actual? Is theistic belief indeed warranted? To answer such problems, it is not enough to hold that "if God exists, then theistic belief is warranted". Additionally, from this conditional, it should be assessed whether we can apply or not modus ponens. That is, we need to work on arguments for and against God's existence. So, I think that the crucial question is to try to show that the $\mathrm{A} / \mathrm{C}$ model (or similar) is indeed actual and, for that reason, it is necessary to show that God exists in order to convince other people that theistic belief has warrant. Thus, we are still in need of natural (a)theology. In this regard, I agree with Swinburne, Fales, and Sennett:

19 By "natural theology" I mean the attempts to show successfully that God exists and by "natural atheology" I mean the attempts to show successfully that God does not exist. 
(Q7) "There is, however, a monumental issue which Plantinga does not discuss, and which a lot of people will consider needs discussing. This is whether Christian [or theistic] beliefs do have warrant (in Plantinga's sense). He has shown that they do, if they are true; so we might hope for discussion of whether they are true" (Swinburne 2001: 206).

(Q8) "Perhaps God has implanted within me a [sensus divinitatis] by the light of which I could come to know Him. [...] But how can I know whether this is so? How can Plantinga know it? Is Plantinga's «model» of our cognitive constitution correct, or merely a just-so story?" (Fales 2003, 358).

(Q9) "While good [propositional] evidence is not required for basic theistic belief to be rational or warranted, good [propositional] evidence may be required in order for it to be shown that basic theistic belief is rational or warranted. The theist requires no [propositional] evidence for the epistemic pedigree of her own basic theistic belief. But if she wishes to convince anyone else that her basic theistic belief is proper, she (or at any rate, someone) must have [propositional] evidence" (Sennett 2003, 230).

By accepting Plantinga's argument for $(\sim \mathrm{T})$, we agree that theistic belief can be warranted in a basic way and, for that reason, the believers in God need not be aware of any arguments for God's existence in order for their beliefs to be warranted. But, for the purpose of showing that the believer's belief is indeed warranted in a basic way, Plantinga or other epistemologist in the theistic community must be aware of good theistic arguments. Thus, even if we grant that Plantinga's argument for $(\sim \mathrm{T})$ is successful, it seems that the conclusion of that argument is insufficient. This is because it appears relevant, at least for the epistemologist, to know whether the $\mathrm{A} / \mathrm{C}$ model is actual or just merely possible, whether theistic belief is indeed warranted in a basic way or not for some people. For such purposes, as well as to convince people outside the theistic community (like skeptics or atheists) that theistic belief is warranted, it is required to work out arguments for and against the existence of God.

This point of mine may be further strengthened when considering other aspects. A widespread objection to Plantinga's religious epistemology tries to hold that Plantinga's argument for thesis $(\sim \mathrm{T})$ can be easily adapted 
and imitated to defend that (i) it is possible that other religious beliefs, as well as other bizarre beliefs (like beliefs in the voodoo or in the Great Pumpkin ${ }^{20}$ ), are warranted in a basic way, and that (ii) such beliefs likely have warrant if they are true. Thus, this objection, which is known as "the Great Pumpkin objection" 21 , seeks to show that weird or bizarre beliefs can be defended in a similar way as Plantinga defends theistic belief. So, Plantinga's argument opens the door to a Pandora's Box in which strange beliefs can be warranted, and in which a diversity of non-theistic religious beliefs (which are contradictory with theistic beliefs) can be warranted. However, if Plantinga's project can be so imitated or adapted, allowing for the possibility of contradictory religious beliefs being warranted and for the possibility of clearly irrational beliefs being warranted, it seems that there is some problem with it. There are several possible formulations of this objection; my own proposal is this:

(1) If theistic belief is intellectually acceptable from the point of view of neutral observers $^{22}$ because such belief is both possible and warranted-if-true, then a bizarre belief, e.g. a Great Pumpkin belief, is also intellectually acceptable from the point of view of neutral observers because such belief is both possible and warranted-if-true.

(2) But, a bizarre belief is not intellectually acceptable from the point of view of neutral observers.

(3) $\therefore$ Therefore, theistic belief is not intellectually acceptable from the point of view of neutral observers. [From 1 and 2]

Now, if conclusion (3) is true, then one of the main objectives of Plantinga (2000: vii) ultimately fails, because it seems that he wanted to show that theistic belief can be considered as intellectually acceptable not only for

20 This is a reference to a Charlie Brown episode in which Linus believes mistakenly that the Great Pumpkin returns every Halloween to give gifts to all the kids.

21 There are various different versions of this objection: Martin (1990), DeRose (1999), Zagzebski (2002), Wunder (2007), Scott (2014).

22 By "neutral observers" I mean rational observers outside the community in issue and who do not share such beliefs (like theistic belief, Great Pumpkin belief, voodoo belief, etc). 
those inside the community of believers, but also for those outside the community of believers (like agnostics, atheists, or neutral observers) or more generally, like Plantinga said, "for educated and intelligent people living in the twenty-first century" (idem). But if this version of the Great Pumpkin objection is correct, from a public point of view there is no reason to think that theistic belief is indeed intellectually acceptable (contrary to what Plantinga thinks). Let's see how we can justify this objection.

Starting with the justification of premise (1), we can suppose that Linus has always believed in the existence of the Great Pumpkin that returns every Halloween and he has such a belief without any inference or arguments. Furthermore, let's presume that he has no defeater for that belief, and even if he has acquired a defeater (for instance, when the Great Pumpkin fails to return every Halloween), he is able to defeat that defeater (for example, conceiving a defense of the Great Pumpkin).

In order to explain how Linus's belief can be warranted in a basic way, one can build a Great Pumpkin model (hereafter "GP model") in all epistemic aspects similar to the $\mathrm{A} / \mathrm{C}$ model and in which the Great Pumpkin belief is properly basic. According to the GP model, there is a cognitive faculty, a sensus cucurbitae, i.e. a pumpkin sense, which was implanted in some chosen and predestined human beings, like Linus, by the Great Pumpkin. When that sensus cucurbitae is working properly, in proper circumstances (like experiences of Halloween), the belief in the existence of the Great Pumpkin is produced in a direct or immediate way with warrant. Thus, on the GP model, the belief in the existence of the Great Pumpkin is produced by cognitive faculties, the sensus cucurbitae, according to a design plan, conceived by the Great Pumpkin, reliably aimed at true. That is, on the GP model, Linus is warranted in believing the Great Pumpkin.

Similarly to what was said about the A/C model, we can add that the GP model is logically possible and that, at least, it is epistemically possible for Linus. Moreover, if there is the Great Pumpkin, it seems likely that the GP model is true and, for that reason, this belief in the existence of the Great Pumpkin is warranted. So, the Great Pumpkin belief is warranted if it is true. Now, if it makes sense that theistic belief is intellectually acceptable 
from a public point of view because there is an $\mathrm{A} / \mathrm{C}$ model and a specific belief that is possible and warranted-if-true, then it also makes sense that the Great Pumpkin belief is intellectually acceptable because there is a GP model and a specific belief that is possible and warranted-if-true. I think that we can build similar models for the voodoo belief, or for other bizarre beliefs. However, justifying premise (2), we need to ask: Is Linus's belief intellectually acceptable from the point of view of neutral observers? Is a bizarre or weird belief in general intellectually acceptable? Intuitively I think not, because it seems to me that there is something wrong with the bizarre or strange beliefs and their origins, for example: they seem to be, by default and for most rational people, merely a just-so story.

But in that case Plantinga's project to defend the intellectual acceptability of theistic belief is not relevantly different, in an epistemic sense, from a strategy one could use to defend bizarre beliefs which are intellectually unacceptable. From the point of view of neutral observers there is no relevant difference between Plantinga's project and any other project to defend unacceptable and bizarre beliefs. These neutral observers, accepting Plantinga's project as well as the imitations of such project, cannot grasp any significant epistemic difference between the theistic belief and the Great Pumpkin belief or other bizarre beliefs. For that reason, if bizarre beliefs, like the Great Pumpkin belief, are not intellectually acceptable for neutral observers, it follows that theistic beliefs are also not intellectually acceptable for neutral observers. Hence, such neutral observers do not have a good reason to consider theistic belief as intellectually acceptable.

From conclusion (3) it does not follow that theistic belief cannot be warranted or that theistic belief is not intellectually acceptable from the point of view of believers in God. So, we may continue to hold that believers in God can have warrant in a basic way, i.e. we may continue to claim that thesis $(\sim T)$ is true. Instead, what follows from my version of the Great Pumpkin objection is that neutral observers do not have any reason to accept the intellectual acceptability of theistic belief in the same way that they have no reason to accept the intellectual acceptability of bizarre beliefs. Thus, Plantinga's project offers no reason why neutral observers 
should take theistic belief more seriously than the Great Pumpkin belief, voodoo belief, or any other bizarre belief. But if this is so, then something seems to be wrong with Plantinga's project.

I think that the best way to cope with this objection is to formulate good arguments for God's existence, showing that the $\mathrm{A} / \mathrm{C}$ model is not only possible but also actual, and arguing that the GP model or the Great Pumpkin is at most merely possible. So, an argument must be provided in order for neutral observers to take seriously that the $\mathrm{A} / \mathrm{C}$ model is likely true and that the same does not apply to the GP model. If this is correct, then we are still significantly in need of a natural theology, of work on arguments for and against God's existence. Thus, I claim that what is wrong with Plantinga's project is not some internal fail on the $\mathrm{A} / \mathrm{C}$ model, but that it is simply incomplete; namely it is unfinished work to argue that theistic belief is possible or warranted-if-true, without arguing for the truth of such belief, in order to establish the acceptability of rational belief from a public point of view.

In short, my thesis is that theistic belief plausibly can be warranted without any theistic argument, but having good theistic arguments is necessary for some purposes, such as the following: to show that the $\mathrm{A} / \mathrm{C}$ model is true or actual; to confirm that theistic belief is indeed warranted for some people; to convince those outside of theistic community that theistic belief is rational or warranted; to cope with the Great Pumpkin objection, and so on. ${ }^{23}$ To achieve these purposes, it is not enough to work on negative apologetics, like Plantinga, arguing that the problem from evil or the problem of divine hiddenness are not good defeaters or reasons to give up theistic belief. Rather, it is also necessary to try to offer some positive apologetic for such theistic belief, formulating good arguments for God's existence.

Perhaps one can resist my thesis, holding that the arguments for God's existence are not necessary for these purposes, and instead that all that is needed is to invite people (like skeptics, agnostics, or others outside the

23 We could also argue that natural theology is necessary because of problems of religious diversity, or to prevent the existence of some defeaters for theistic belief, etc. 
theistic community) to participate in appropriate circumstances $\mathrm{C}$ (like the circumstances of praying, reading the Bible, etc). However, it seems that such strategy may not work. On the one hand, even if such people find themselves in circumstances $\mathrm{C}$, it does not follow that they will form warranted theistic beliefs; for example, in situations in which there is no God, or in which the sensus divinitatis is malfunctioning, etc. On the other hand, that strategy can be imitated by other religions or still by communities which hold bizarre beliefs. Thus, to avoid falling in such problems, I think that the best way to fulfill those purposes is by working on arguments for and against God's existence.

\section{Acknowledgements}

Thanks to Pedro Galvão, Ricardo Santos, John Greco, Tyler Wunder, Kyle Scott, Anthony Bolos, Elia Zardini, David Yates, Célia Teixeira, Diogo Santos, José Manuel Mestre, and Vitor Guerreiro for helpful comments and discussion on an earlier version of this paper. I am also grateful to two anonymous referees for useful comments and suggestions. Any errors or omissions are my responsibility. Work for this paper was supported by a doctoral fellowship (SFRH/BD/85051/2012) awarded by the Portuguese Foundation for Science and Technology.

\section{References}

Alston, William. 1991. Perceiving God: The Epistemology of Religious Experience. Ithaca: Cornell University Press.

Beilby, James. 2007. “Plantinga's Model of Warranted Christian Belief.” In Alvin Plantinga, edited by Deane-Peter Baker, 125-165. Cambridge University Press. Bergman, Michael. 1997. "Internalism, Externalism, and the No-Defeater Condition”. Synthese, 110: 399-417.

Bergmann, Michael. 2012. "Rational Religious Belief without Arguments." In Philosophy of Religion: An Anthology, edited by Louis Pojman \& Michael Rea, 534-549. Wadsworth Publishing. 
Dawkins, Richard. 1995. “A Reply to Poole.” Science and Christian Belief 7(1): 45-50. DeRose, Keith. 1999. "Voodoo epistemology.” Unpublished manuscript, <http:// pantheon.yale.edu/ kd47/voodoo.htm>.

Draper, Paul and Trent, Dougherty. 2013. "Explanation and the Problem of Evil.” In The Blackwell Companion to the Problem of Evil, edited by Justin P. McBrayer and Daniel Howard-Snyder, 67-82. Wiley-Blackwell.

Evans, Stephen. 2011. "Religious Experience and the Question of Whether Belief in God Requires Evidence.” Evidence and Religious Belief, edited by Kelly James Clarck, 37-51. Oxford University Press.

Fales, Evan. 2003. “Critical Discussion of Alvin Plantinga's Warranted Christian Belief.” Noûs, 37: 353-370.

Greco, John. 2008. “Friendly Theism.” In Religious Tolerance through Epistemic Humility, edited by James Kraft, 51-58. Aldershot: Ashgate.

MacIntosh, J.J. 2000. “Locke, Plantinga, and the A/C model.” In Papers from the book symposium on Alvin Plantinga's Warranted Christian Belief. <http://people.stfx. ca/wsweet/Plantinga-MacIntosh.html>.

Mackie, John. 1983. The Miracle of Theism: Arguments for and Against the Existence of God. Oxford University Press.

Martin, Michael. 1990. Atheism: A Philosophical Justification. Philadelphia: Temple University Press.

Miller, Christian. 2005. "Defeaters and the Basicality of Theistic Belief.” In Basic Belief and Basic Knowledge: Papers in Epistemology, edited by Ron Rood, 147-176. Ontos Verlag.

Moser, Paul. 2008. The Elusive God: Reorienting Religious Epistemology. Cambridge University Press.

Oppy, Graham. 2009. Arguing about Gods. Cambridge University Press.

Plantinga, Alvin. 1993a. Warrant: The Current Debate. Oxford University Press.

Plantinga, Alvin. 1993b. Warrant and Proper Function. Oxford University Press.

Plantinga, Alvin. 2000. Warranted Christian Belief. Oxford University Press.

Plantinga, Alvin \& Tooley, Michael. 2008. Knowledge of God. Blackwell Publishing.

Plantinga, Alvin \& Boyce, Kenneth. 2012. “Proper Functionalism.” In The Continuum

Companion to Epistemology, edited by Andrew Cullison, 124-140. Continuum Press.

Plantinga, Alvin. 2015. Knowledge and Christian Belief. Eerdmans Publishing Co.

Scott, Kyle. 2014. “Return of the Great Pumpkin.” Religious Studies 50: 297-308.

Sennett, James. 2003. "Reformed Epistemology and the Rationality of Theistic Be-

lief.” In God Matters: Readings in the Philosophy of Religion, edited by Ray Martin, 219-231. Longman. 
Sobel, Jordan. 2003. Logic and Theism: Arguments For and Against Beliefs in God. Cambridge University Press.

Stump, Eleonore. 2010. Wandering in Darkness: Narrative and the Problem of Suffering. Oxford University Press.

Swinburne, Richard. 2001. “Plantinga on Warrant.” Religious Studies 37: 203-214.

Swinburne, Richard. 2004. The Existence of God. Oxford University Press.

The World Factbook 2013-14. Washington, DC: Central Intelligence Agency, 2013, <https://www.cia.gov/library/publications/the-world-factbook/index.html>.

Wilson, Edward. 1978. On Human Nature. Harvard University Press.

Wolterstorff, Nicholas. 1988. "Faith.” In The Routledge Encyclopedia of Philosophy, <https://www.rep.routledge.com/articles/faith/>.

Wunder, Tyler. 2007. Warrant and Religious Epistemology: A Critique of Alvin Plantinga's Warrant Phase. Boston University.

Zagzebski, Linda. 2002. "Plantinga's Warranted Christian Belief and the Aquinas/ Calvin Model.” Philosophical Books 43: 117-123. 